\title{
The Conceptual Basis for The Formation of a Single Educational Space
}

\author{
Nadezhda Pavlova ${ }^{1 *}$ \\ ${ }^{1}$ Moscow State Pedagogical University, Institute of Pedagogy and Psychology of Education, \\ Department of Pedagogy, Moscow, Russia
}

\begin{abstract}
The article deals with the study of educational trends at global and national levels. The purpose of the research is to study and analyze the conceptual foundations of the creation of a unified educational space. The main research methods involve studying literary sources, conducting theoretical analysis, and employing logical generalization methods. The research conducted allowed revealing the conceptual foundations of the unified educational space formation. The article identifies reference trends that characterize crisis developments in educational activities at the global and national levels. It is determined that in the conditions where humanity has come close to the borders of its existence on a global scale, the traditional universal values laid down in the foundation of modern man-made civilization will ensure its survival. In this regard, the task of the educational system based on universal human values is to develop knowledge and the foundations of existence that ensure the survival of civilization. Above all, this should be a philosophy of conservation and sustainable development.
\end{abstract}

\section{Introduction}

Globalization has the strongest influence on almost all social processes, both in terms of their content and forms of manifestation [1]. It requires a change in the system of self-government of civilization, which, in turn, requires a change in the traditional style of thinking, traditional ways of resolving contradictions, and conventional value orientations.

Speaking about the formation of a single global educational space, it can be noted that it not only modifies education in terms of its content but also leads to the standardization and unification of educational systems of states that are part of the educational space [2]. Unified educational space is impossible without common requirements for education quality and standard. These steps lead to uniformity in education, and the loss of the national component of education.

The contemporary education system in the world and Russia in the era of globalization can be characterized as a system devoid of internally definite and clear goals. Speaking about the formation of a unified educational space, educational organizations, adhering to the principle of variability, develop their training and educational programs, as well as their goals and objectives [3], that is, everything that eventually leads to the blurring of the unified educational space and affirms the worldview and moral relativism in the entire educational

\footnotetext{
*Corresponding author: mapav1@yandex.ru
} 
system. The goal of the present article is to identify the conceptual foundations of the unified educational space being formed at the global and national levels.

\section{Methods}

The research was conducted based on a theoretical analysis of the problem under consideration, based on scientific principles. The substantial body of scientific guidelines used to solve the set problem includes the following principles: the principle of systematicity, i.e. everything should be based on a system; the principle of evolution: the main form of life is a movement and becoming rather than being at rest; the principle of additionality: the ability to describe social and cultural dynamics processes through a variety of models, as well as the principle of historicism. These methods of analysis allowed for solving the set problem.

\section{Results and discussion}

The formation of a unified educational space in Europe falls on the modern age $\left(17^{\text {th }}-18^{\text {th }}\right.$ centuries). The quintessence of pedagogy of this period was the connection of Christian moral norms with the scientific picture of the world. A systematic solution to the problem for that time was proposed by Jan Amos Komensky (1592-1670), the Czech teacher, systematician, and popularizer of the class-lesson system. In his book "The Great Didactic", Komensky connects science with Christianity while giving priority in education to scientific knowledge [4].

Also, in his work "General advice to the human race on improving human affairs", Komensky described and proposed a model of world governance at three levels in conjunction with the formation of a single educational space.

The first level is political, involving the creation of international institutions that would govern politics on a global scale.

The second level is religious, the creation of a syncretic religion that would also be governed by a single consistory.

And the third level, the most important and the highest, is a system that unites scientists as knowledge carriers who develop the principles of education.

According to Komensky's hierarchy, scientists were attributed to the first level, church to the second level, while politics - to the lowest third level. Thus, the policymakers were treated as managers who should implement decisions made at higher levels. Subsequently, his ideas were presented in the core documents of UNESCO, the organization designed to set standards in the field of science, education, and upbringing. It is no coincidence that that in 1946, the first Secretary-General of UNESCO was Julian Huxley, an adherent of Kamensky's humanistic ideas.

Huxley assumed that organic evolution was mainly limited to the development of specializations, and interpreted it as an increase in the efficiency of adaptation to a particular lifestyle. But specialization is always associated with the need to sacrifice some bodies or functions for others to work more effectively, which limits the possibility of future changes [3].

It should be recognized that in the $20^{\text {th }}$ century, one of the most significant events in the field of education which claimed to form a unified system of governance was the report "Crisis of democracy", which was elaborated in 1975 by order of the "Trilateral Commission". Democracy, a highly educated society, and a high degree of political involvement of the masses in government were identified in the report as a threat to democracy for the capitalist elite, whereas, in contrast, the lack of involvement of the masses in politics was the basic recipe for preserving the power of the capitalist elite. 
This partly explains the strengthening of the postmodern orientation of the contemporary world and domestic education system, which leads society to a civilizational impasse, because it does not give clearer scientific picture of the world [5].

A significant role in the unification of the world educational space was played by Robert Mueller, who was called the "father of global education". He was the permanent DeputySecretary-General of the United Nations for forty years and participated in, or led the development of thirty-three UN programs. But most importantly, he was responsible for the education system. His book entitled "New Genesis" sets out the principles for regulating education through educational programs. Besides, Mueller also offered a worldwide schedule of lessons that should be taught to all children globally $[6,7,8,9]$.

The first document concerning the restructuring of education that was developed in Europe was prepared on the platform of the organization called "Round Table of European Industrialists" at which the report of 1989 was presented $[10,11]$. The same report stated that "education and training are seen as vital strategic investments for the future success of the enterprise", and "teachers do not understand enough about business economic activity and the concept of profit, therefore it will be necessary to give greater importance to distance learning" [12].

In December 2014, the "Concept of Education for 2016-2020" was adopted, which was developed by the National Research University Higher School of Economics, where improving the quality of education, which was possible with the transition to distance learning, was the main idea [13].

In 1991, a report was published entitled "The Open University is an industrial enterprise, while distance learning is a new industry". Besides, six months later, the European Commission published a "White Paper" in which terms such as flexibility, mobility, and employment were used concerning education and research.

Subsequently, the Sorbonne Declaration of 1997 prepared the Bologna Process intending to create an open European higher education area, designed to become "more competitive in the world market of educational services". Although the Sorbonne Declaration confirmed the traditional principles of university activity, it introduced new key concepts of mobility, flexibility, and employment, which meant the beginning of adaptation to the market $[2,14]$.

In 1999, the ministers of education of 29 countries signed the well-known Bologna Declaration "The European Higher Education Area (EHEA)", which was joined by 47 countries. The Bologna system declared the following goals:

- building the European higher education area as a key direction for the development of citizens' mobility with the possibility of employment;

- ensuring the competitiveness of universities in the fight for students, money, and influence;

- achieving greater compatibility and comparability of national higher education systems [14].

In the Russian educational system, the process of transferring to distance learning is underway [15]. According to the special representative of the President of the Russian Federation, there will be different models of universities in the future. Fundamental education is necessary, but it must stand at the top of the education pyramid. In Russia, 200-250 universities should remain in the next ten years. It is supposed to divide future education into two types - computer-based, which will be cheap, and human-based, which will be expensive because knowledge is rapidly devalued, while social connections and the opportunity to learn on a face-to-face basis will become more expensive.

Concluding the issue of digitalization, it should be noted that at the panel of the WorldSkills-2019 conference in Kazan, a discussion was held by Nassim Taleb, special representative of the President of the Russian Federation and author of the "Black Swan" theory. 
In his speech, Taleb stressed that the most valuable skills in life are not the skills of working with the known things, but the skills of working with uncertainty, as well as the ability to earn money from it. However, he did not explain how to work with these uncertainties.

The special representative of the President of the Russian Federation invited the conference participants to predict what skills should be formed in the future and how to evaluate them: "On the one hand, we face the challenge of uncertainty, while on the other hand, there is a challenge associated with the need to acquire new skills. The world is becoming less predictable, and the need for specific skills is decreasing. And the question arises: why do we need the WorldSkills movement? But there is another part of the question: what are skills? What skills do we develop as part of the WorldSkills movement? What is more important to develop: a skill as a result, for example, in an exam, or is it about our willingness to work with uncertainty? What do we evaluate in the educational process performance on an exam or cognitive style when one faces a particular challenge? What is the response to the challenge, the readiness to face it and find an answer?"[12,16].

In the authors' opinion, the main motivator of the crisis of the educational system is the lack of awareness of what is happening and, as a result, the uncertainty of the ideals of the individual and society in the context of the contemporary scientific and technological revolution and globalization [17].

\section{Conclusion}

Thus, the formation of a worldview is not a forced change in the system of a person's worldview for the sake of profit of transnational corporations but the creation of a competitive mechanism for different value systems and behavior models allowing making personal choices based on personal reflection. The unified educational space that is being formed should make a person a true goal, while all forms of activity should be reasonable.

Therefore, the education system should not only be sensitive to all the achievements of scientific thought and the needs of social practice but also be constantly focused on the future: the more fully and flexibly the education system responds to the demands of life, the more powerfully it influences the development of other sectors of society. Therefore, one of the priorities is to create such an educational system at both the global and national levels.

\section{References}

1. S. Forsberg, Geoforum 100, 32-40 (2019)

2. Making the Most of Our Potential: Consolidating the European Higher Education Area, Communiqué of the Conference of Ministers responsible for Higher Education in Bucharest, Romania (2012) Available at: http://www.ehea.info/Upload/document/ministerial_declarations/Bucharest_Communi que_2012_610673.pdf

3. J. Huxley, The wonderful world of evolution (Mir, Moscow, 1971)

4. Ya.A. Komensky, Selected pedagogical essays (Pedagogy, Moscow, 1982)

5. K.R. Bayanov, Philosophical and methodological foundations of forecasting socionatural dynamics: abstract of dissertation for the degree of Doctor of Philosophy, (Moscow State Academy of Business Administration, Moscow, 2011)

6. B. Schlink, New Age from the point of view of the Bible (Evangelische Marienschwesternschaft, Darmstadt-Eberstadt, 1992). 
7. A single educational space as a guarantee of sustainable development of Russian education. Available at: http://tretjak-natalja.ru/edinoe-obrazovatelnoe-prostranstvo/

8. T.B. Zemlyanaya, O. N. Pavlycheva, Russia in the global educational space: information and analytical material (INIPI RAO, Moscow, 2011)

9. P.A. Nikolaychuk, Video Science: Network Journal 2(6), (2017) Available at: https://videonauka.ru/stati/37-spetsialnyj-vypusk/123-o-perspektivakh-vkhozhdeniyarossii-v-mirovoe-obrazovatelnoe-prostranstvo

10. K. Lee, H. Choi, Y. H. Cho, The Internet and Higher Education 41, 25-33 (2019)

11. C. Sanchez, L. Intel, S. Blog, The use of technological resources for education: a newprofessional competency for teachers (Intel, 2013)

12. A. Bozkurt, E. Akgun-Ozbek, S. Onrat-Yilmazer, E. Erdogdu, International Review of Research in Open and Distributed Learning 16(1), 330-336 (2015)

13. K.R. Bayanov, The history and philosophy of education: a scientific and training manual (Print Torg, Glazov, 2018)

14. G. Telegina, H. Schwengel, European Journal of Education 47(1), 37-49 (2012)

15. C. Herodotou, B. Rienties, M. Hlosta, A. Boroowa, C. Mangafa, Z. Zdrahal, The Internet and Higher Education 45, (2020)

16. WorldSkills Conference (Kazan, 2019) Available at: https://worldskillsconference.com/2019/ru/

17. K.R. Bayanov, N. P. Pavlova, Almanac of the Center for Social Sciences and Faculty of Economics, Lomonosov Moscow State University 6(120), 222-231 (2018) 